Editorial

\title{
Introduction to the Special Issue "Policing Ethnicity: Between the Rhetoric of Inclusion and the Policies and Practices of Exclusion"
}

\author{
Abby Peterson ${ }^{1, *}$ and Malin Åkerström ${ }^{2}$ \\ ${ }^{1}$ Department of Sociology and Work Science, University of Gothenburg, 40530 Göteborg, Sweden; \\ E-Mail: abby.peterson@sociology.gu.se; Tel.: +46-31-7864793 \\ ${ }^{2}$ Department of Sociology, University of Lund, 22100 Lund, Sweden; E-Mail: malin.akerstrom@soc.lu.se \\ * Corresponding author
}

Submitted: 6 July 2014 | Published: 17 September 2014

\begin{abstract}
Issue
This editorial is part of the special issue "Policing Ethnicity: Between the Rhetoric of Inclusion and the Practices and Policies of Exclusion", edited by Professor Abby Peterson (University of Gothenburg, Sweden) and Professor Malin Åkerström (University of Lund, Sweden).
\end{abstract}

(C) 2014 by the authors; licensee Cogitatio (Lisbon, Portugal). This article is licensed under a Creative Commons Attribution 4.0 International License (CC BY).

On the one hand European countries talk the humanitarian and cosmopolitan politics of inclusion of ethnic minorities with a battery of integration policies, on the other hand these same societies practice the policies and practices of exclusion. In this special issue we address this disjuncture and what we refer to as the European moral dilemma, in much the same way that Gunnar Myrdahl, in his influential study from 1944-The American Dilemma-pointed out that the oppression of Black people living in the US was at odds with the country's moral grounds, its founding creed that all men are created equal and are endowed "with certain unalienable Rights, that among these are Life, Liberty and the pursuit of Happiness" (Declaration of Independence). This special issue does not only include articles from European contexts, however the majority are analyses of European ethnic minority policies and practices. Nonetheless, all of the articles address in different ways how the rhetoric of inclusion is all too often at odds with the practices and policies of exclusion and control. In focus is what we call the policing of ethnicity, that is, the governance of inclusion and exclusion along ethnic lines.

Policing in its broadest sense will be defined as all of those activities involved in the provision of security and/or the maintenance of the social-economic order. While public police authorities and other state institutions with constabulary powers remain the focal for this type of social control, policing by the state has been joined by a multitude of policing providers locally, nationally and transnationally. During the last thirty years we have experienced a dramatic transformation in policing resulting in what Loader (2000) and Jones and Newburn (2006) have called "plural policing", or what Crawford (1997), among others, has called the "extended police family", or what Bayley and Shearing (2001) have called "multilateralization". We are now confronted with the recognized reality of a wide diversity of agencies and agents, both networked and fragmented that together are responsible for the delivery of policing and security services and technologies. 'Policing' is now both authorized (by economic interests, both legal and illegal; residential communities; cultural communities; individuals; and governments); and delivered by diverse networks of commercial bodies, voluntary and community groups, individual citizens, national and local governmental regulatory agencies, as well as the public police. This network of policing agencies and agents extends beyond the direct provision and supervision of policing by the state, to include policing forms secured through government; to the rapid expansion of the private security industry providing policing beyond government; to transnational policing arrangements unfolding above government; to citizen initiatives in policing activities and corporate forms of self-regulation below government. The special issue in- 
cludes articles, which address the plethora of policing instances. How is ethnicity impacting the new multiple modes of policing and what are their consequences for the everyday lives of ethnic minorities today?

Policing ethnicity within the nation-state is engaged with securing the borders of segregated urban (and even rural) landscapes. Within the nation-state there is a high degree of ethnic coding of spatial borders between urban areas perceived as more or less secure and those areas, the socio-economic marginalized housing estates with a high ethnic minority density often (often but not always, see Wästerfors and Burcar, this issue) surrounding urban centres, where the threat of crime and the prospect of meeting violence is perceived as high. The movements of ethnic minorities within these 'high risk' areas, as well as the movements of ethnic minorities beyond these internal borders, are policed by a plethora of agencies and agents involved in the provision of security and/or the maintenance of the ethnicized social-economic order-of controlling a 'suspect population'.

The articles in this special issue interrogate in different ways policing as the patterns of social control, or governance of inclusion and exclusion, along the dynamic and interrelated dimensions of ethnicity, class and gender. Questions posed are: How is the provision of (physical) security by the new multiple modes of policing constructing a topography of 'insiders' who enjoy the benefits of policing and 'outsiders' who bear the burdens? Who and in what ways are some consigned to the 'outside' and others are invited 'inside'? How and in what ways are countries policing their borders, both internal and external?

The issue focuses on how ethnicity is policed, the instruments that governments use to govern the conduct of ethnic minorities, their ways of life and the experience of their identities. While ethnicity-a status as immigrant or asylum seeker-is a powerful trope for social sorting and the policing efforts of exclusion, poverty and gender are enduring criteria for social sorting. Ethnicity, class, and gender come together in new ways to define people as flawed producers or consumers, "social pollutants" (Urry, 1995), and therefore targets for exclusion from, and control within, the new social and economic order (cf. Bosworth, Bowling, \& Lee, 2008).

Following Foucault's line of thinking, modern societies are adapting normalizing disciplinary strategies, moving from more punitive forms of institutional discipline to 'softer', incentive-based forms. Furthermore, the 'problem' of exclusion is individualized, as are integration policies aimed at including ethnic minorities in social, political and working life individualized. Erika Gubrium and Ariana Guilherme Fernandes explore policing as a disciplinary means for governing ethnic minority welfare recipients towards a desired behaviour. Presuming cultural marginality and passivity, particularly among female immigrants and refugees arriving from countries other than from Europe, North America or Australia, they have found that the so-called activation programmes they have analysed are designed to steer women into the labour market and away from the home. While these authors focus the 'deserving citizen' where the assessment of deservingness is strongly based on work ability, Nicolas Van Puymbroeck, Paul Blondeel and Robin Vandevoordt focus the 'good citizen'. They interrogate the tension between the city of Antwerp's ostensibly universal rhetoric of inclusion with its slogan 'Antwerp belongs to everyone' and its exclusionary policies targeting ethnic minorities whose behaviour fails to comply with the municipality's conception of what the 'normal' conduct of its inhabitants ought to be-the ethnicized standard of the 'good citizen'.

The theme of the 'good citizen' also rears its head in European debates on Muslim women bearing veils. Analysing parliamentary debates over the headscarf in France, Germany and the Netherlands Doutje Lettinga and Sawitri Saharso found that historically entrenched citizenship models did indeed help to frame how each of the countries perceived the social inclusion of Islamic women, which has led to different regulations for bearing the headscarf. However, they point out that these models are not static and should rather be regarded as schemas that help frame the discursive battles over citizenship in processes of policy formation. Furthermore, they could detect a certain convergence in all of the three countries in which the framing of headscarves as a symbol of gender inequality and oppression gained strength when polarization around Islam increased and xenophobic populist voices emerged.

Thomas Friis Sørgaard in his article has also studied the urban rejuvenation and 'branding' projects of municipal governments, calling into question the universalist cosmopolitan rhetoric of inclusion with the reality of neoliberal and market-driven forms of ethnic governance that through the practices of private security doormen or 'bouncers' effectively exclude ethnic minority young men deemed as 'gangstas' and working class and under class ethnic Danish men from the nightlife economy in the Danish city of Aarhus. His case study of bouncers' administration of nightlife accessibility sheds light on the ongoing ethnicized processes of inclusion and exclusion in the so-called and highly touted 'cosmopolitan' city. Bouncers are examples of policing actors patrolling the micro-boundaries of urban life's micro-spaces (Franzén, 2001).

How are the micro-boundaries of these microspaces policed? An ubiquitous thread running through the practices of policing agents keen on anticipating 'trouble' is racial profiling, or what is more often referred to in European contexts as ethnic profiling. Racial or ethnic profiling is more or less tacitly regarded by policing practitioners (and many academics alike) as an indispensible and effective tool for their crime finding and crime fighting efforts. Trevor George Gardner 
critically engages with the literature (pro and con) on racial profiling focussing on the social construction of race in the context of racial profiling. Meanings are attached to racial classifications through rhetoric, policy, explicit and implicit symbolism and role-play. He argues that "when police engage in racial profiling race and criminality take shape as co-constituted social constructs that inform a sense of racial hierarchy" -in the minds of the profiler, the profiled, and the society at large. Hence, racial profiling is not an innocuous tool in the hands of crime-fighters, rather racial profiling underpins society's constructions of 'suspect populations', making possible pervasive forms of collective exclusion.

Anne Rienke van Ewijk compares what she calls the 'diversity discourses' in two police authorities, the one in Catalonia and the other in the Netherlands, highlighting similarities and differences is their definitions of diversity and motives for diversity policies. Cecilia Löfstrand Hansen and Sara Uhnoo analyse 'diversity policing', i.e. the promotion of ethnic diversity in the police actors' workforces, and 'policing diversity', i.e. how the policing of ethnic diversity is performed on the ground by two policing actors-on the one hand the municipal police authority and one the other, a private security company. The authors found markedly similar discourses and practices at play within both public and private policing actors. While the official discourses in both contexts emphasized diversity policing with an ethnic diverse workforce as a socially responsible recruitment strategy and as a valuable resource for the effective execution of their policing tasks and the legitimacy of their actions, a more unofficial discourse on ethnicity using ethnicized stereotypes of the 'criminal other' highly influenced their day-to-day work-policing diversity. In both contexts diversity policing, what was perceived unofficially as strategically necessary for their effectiveness, underpinned the stereotypical policing diversity at the street level, which in turn perpetuated the stereotype of the criminal 'foreign' other.

Much like in Löfstrand Hansen's and Uhnoo's study, David Wästerfors and Veronica Burcar, in their study of safety work by municipally employed safety 'wanderers' in the 'troubled centre' of a small Swedish city, found that ethnic minorities were both the target of their safety work and at the same time a resource for carrying out their safety function-all of the eight 'blue jackets' safety workers were young people with ethnic minority backgrounds. As one of the blue jackets explained the situation, 'immigrants were selected to control other immigrants'. The authors' sensitive ethnographic fieldwork uncovered the subtle ways that ethnicities and ethnic hierarchies are produced and reproduced in 'soft' policing-reinforcing the image of norm violation as typically 'un-Swedish' and threats to public order as emanating from the ethnic minority 'others'.

Tove Pettersson turns our attention to a core policing actor-the police authorities, and their interactions with ethnic minority young men in socio-economic marginalized areas in metropolitan Stockholm. Departing from a procedural justice perspective, Pettersson concurs with previous research that ethnic minority youth often express complaints, which are to a large extent about unfair treatment. However, she also concluded that the young people are at the same time often willing to take the time and effort to give voice to their discontent with the police. Furthermore, met with respect and understanding by police officers, these encounters provide the police authorities opportunities to enhance cooperation with ethnic minority youth and thereby conduct their policing mandate more effectively.

Policing ethnicity is a question of controlling spatial borders against the perceived threats posed by ethnic minorities to stability, order and social cohesion (Garner, 2007). Policing ethnicity at the nation-state's borders, what Weber and Bowling (2008) call "policing migration", is a transnational issue, where the flows of people-immigrants and asylum-seekers-are constructed as a security question. Within the European Union migration has been increasingly presented as a danger to public order, cultural identity, and domestic and labour market stability; in short, according to Huysmans (2000), migration has been securitized. Within the EU Bigo (1994) has argued that by making border control a security problematique between EU member-states, and to various degrees within individual nation-states, immigrants and asylum-seekers are per definition connected to terrorism, criminal activities, drugs and people trafficking, etc.

Kenneth Horvath, using the case of Austria, examines what he claims are increasingly harsher forms of border policing emerging in neoliberal societal contexts corresponding to what Löic Wacquant (2009) has called the 'neoliberal Centaur state'-liberal at the top promoting the mobility of socio-economic elites and punitive forced immobilization at the bottom, relying on detention and deportation of unwanted migrant labour and refugees. The new forms of migration regimes emerging, he argues, operate with more differentiating criteria and more and more polices mobility itself at its borders.

Concluding our special issue is an under-researched topic-why and how cultural communities police themselves. Policing ethnicity, understood in its broadest sense as the governance of inclusion and exclusion, opens for an understanding as to how, paradoxically, ethnic minorities and ethnic minority actors can also be implicit in processes of ethnification and exclusion. Widening our geographical range from our European focus, Terence Christopher Moore critically engages with the Australian governmental policies of Aboriginal inclusion. He suggests that governmental policies, while at first blush are progressive, rest upon a singular bounded category and Aboriginal ideal type, which does not correspond with the lived realities and fractured subjectivities of Aborigines living in Australia to- 
day. Cultural recognition of an Aboriginal otherness underpins a ceiling to social inclusion under which persistent inequalities and continued socio-economic marginality flourish. While the state bears responsibility for the only partial inclusion of Aborigines, Aborigines themselves are also agents in their relationship with the wider society. Moore argues that Aboriginal political elites, with vested power interests in the 'Indigenous Sector's' affairs, police the performance of an Aboriginality that for authenticity requires exaggerated and mythic difference and resistance to state inclusionary efforts. In this way, Aborigines' marginality and victimhood are maintained.

In this special issue we have strived to include the breadth of ways ethnic minorities are policed and their behaviour governed, thereby opening for further research on the subtle ways within multileveled spaces that ethnic minorities are the subject of enduring processes of control, differentiation and exclusion. The articles all show how the liberal rhetoric of inclusion and equality is fundamentally at odds with the realities ethnic minorities are facing in society.

\section{References}

Bayley, D., \& Shearing, C. (2001). The New Structure of Policing. Research Report from the National Institute of Justice. Washington: Department of Justice.

Bigo, B. (1994). The European Internal Security Field: Stakes and Rivalries in a Newly Developing Area of Police Intervention. In M. Anderson \& M. Den Boer (Eds.), Policing Across National Boundaries (pp. 161-
173). London: Pinter.

Bosworth, M., Bowling, B., \& Lee, M. (2008). Globalization, ethnicity and racism. Theoretical Criminology, 12(3), 263-273.

Crawford, A. (1997). The Local Governance of Crime: Appeals to Partnerships and Community. Oxford: Claredon.

Franzén, M. (2001). The Urban Order and the Preventive Restructuring of Space: The Operation of Border Controls in Micro Space. The Sociological Review, 49(2), 202-218.

Garner, S. (2007). The European Union and the Racialization of Immigration 1985-2006. Race/Ethnicity, 1(1), 61-87.

Huysmans, J. (2000). The European Union and the Securitization of Migration. Journal of Common Market Studies, 38(5), 751-777.

Jones, T. J., \& Newburn, T. N. (Eds.) (2006). Plural Policing: A Comparative Perspective. London and New York: Routledge.

Loader, I. (2000). Plural Policing and Democratic Governance. Social Legal Studies, 9(3), 323-345.

Myrdal, G. (1944). An American Dilemma, Volume 2: The Negro Problem and Modern Democracy. New Brunswick: Transaction Publishers.

Urry, J. (1995). Consumer Spaces. London: Routledge.

Wacquant, L. (2009). Punishing the Poor. The Neoliberal Government of Social Insecurity. Durham and London: Duke University Press.

Weber, L., \& Bowling, B. (2004). Policing Migration: A Framework for Investigating the Regulation of Global Mobility. Policing \& Society, 14(3), 195-212.

\section{About the Authors}

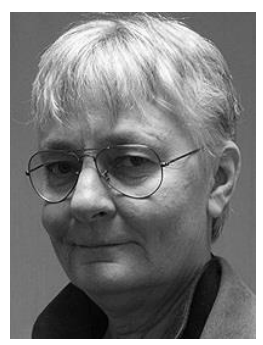

\section{Dr. Abby Peterson}

Abby Peterson is Professor of Sociology at the Department of Sociology and Work Science, University of Gothenburg. She has published widely within the fields of social movement research and criminology.

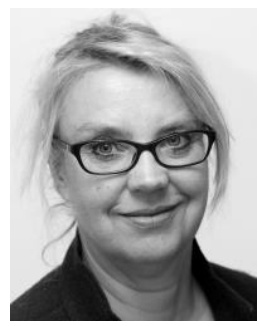

\section{Dr. Malin Åkerström}

Malin Åkerström is Professor of Sociology at Lund University in Sweden. Her research focuses on ethnographic studies of deviance. She has published several books, including Suspicious Gifts: Bribery, Morality, and Professional Ethics, Betrayers and Betrayers and Crooks and Squares, and articles such as "Doing Ambivalence: Embracing Policy Innovation-At Arm's Length", "Slaps, Punches, PinchesBut not Violence: Boundary Work in Nursing Homes for Elderly" and "Balancing Contradictory Identities-Performing Masculinity in Victim Narratives", as well as several articles on qualitative methods. 